\title{
Grazing Capacity, Sheep Gains: Cheatgrass, Bunchgrass Ranges in Southern Idaho ${ }^{1}$
}

\section{ROBERT B. MURRAY2}

Associate Range Scientist, Intermountain Forest and Range Experiment Station, Forest Service, U.S. Department of Agriculture, Ogden, Utah; stationed in Boise, Idaho.

\section{Highlight}

Comparisons were made of grazing capacities and sheep gains on both cheatgrass range and on native bunchgrass range during early spring. Capacities were similar on these two range types in wet years, but were almost $60 \%$ greater on bunchgrasss range during dry years. Sheep gained an average of $0.32 \mathrm{lb}$. per head per day over three spring periods on the two vegetation types. In 2 of the 4 study years, they lost weight during the first 2-week grazing period. Sheep gains per acre were similar on the two range types.

The dearth of information on cheatgrass range led to a cooperative research project initiated by the Bureau of Land Management, U. S. Department of the Interior, and the Intermountain Forest and Range Experiment Station, Forest Service, U. S. Department of Agriculture. The Saylor Creek Experimental Range was established in 1960 near Glenns Ferry, Idaho.

One of the major objectives of the research at Saylor Creek Experimental Range is to determine whether it is desirable and feasible to convert cheatgrass (Bromus tectorum) range to perennial grass range. Comparisons were made of grazing capacities and sheep gains on cheatgrass range and on native needle-and-thread (Stipa comata) bunchgrass range under heavy use during early spring in the years, 1960-1964.

Ordinarily, cheatgrass and bunchgrass ranges in southern Idaho are grazed by sheep from late March to early June, before forage maturcs. Consequently, comparison of the two range types during this part of the grazing season is appropriate. Bunchgrass ranges with extended green-feed periods may offer additional forage and result in greater overall gains and capacities.

\footnotetext{
${ }^{1}$ Received December 30, 1970.

${ }^{2}$ Acknowledgrnent is made to Dr. J. O. Klemmedson, now Professor, Department of Watershed Management, University of Arizona, Tucson, for design of the study.
}

Cheatgrass grows over a wide area in southern Idaho, but little is known about the forage quality for sheep or the grazing capacity of these ranges. Murray and Klemmedson (1968) reported on these aspects for yearling cattle over a 7-month season (April-November). In Utah, Cook and IIarris (1952) found that sheep gained $0.05 \mathrm{lb}$. per head per day on cheatgrass that ranged in age from boot to maturity.

\section{Description of the Area}

The experimental range is on a level to gently undulating site typical of many range areas on the Snake River Plain. Soils, which were derived from sedimentary and windblown materials deposited over basalt (Malde and Powers, 1962), vary in texture from sandy to silty loams.

Precipitation records for the 1905-1959 period show a yearly average of 8.84 inches at Glenns Ferry. During the study period (1960-1964), precipitation at the experimental range averaged 9.48 inches annually. The low and the high were 7.18 and 13.43 inches in 1961 and 1963, respectively.

Average annual air temperature at the experimental range during the 1960-1964 period was $51.9 \mathrm{~F}$. Temperatures during the spring may drop below freezing and, occasionally, rcach the nineties. Table 1 gives precipitation; maximum, minimum, and average tem- peratures; and cheatgrass yield at Saylor Creek.

The study area includes pastures that are predominantly cheatgrass or bunchgrass types; both vegetation types are seral stages of the big sagebrush-Thurber needlegrass (Artemisia tridentata-Stipa thurberiana) climax. ${ }^{3}$ Repeated burning and excessive grazing have reduced the climax to the present vegetation. Cheatgrass range includes cheatgrass as the dominant species and varying amounts of Sandberg bluegrass (Poa secunda), streambank whcatgrass (Agropyron riparium), and annuals such as Russianthistle (Salsola kali v. tenuifolia) and mustards (Sisymbrium altissimum and Descurainia pinnata). Bunchgrass range is dominated by needle-and-thread, but contains Thurber's needlegrass (Stipa thurberiana), Indian ricegrass (Oryzopsis hymenoides), and big squirreltail (Sitanion hystrix), as well as cheatgrass and other annual forb species. Table 2 gives the estimated percent species composition of pastures in the cheatgrass and bunchgrass types (data taken from 20 quadrats per pasture).

\section{Study Methods}

Yearling sheep, mostly dry ewes of mixed range-breeds (Rambouillet, Targhee, and Columbia) provided by local sheepmen, were allowed to graze for three consecutive 2-week periods beginning in early April each test year (Table 3). Each 2-week treatment was replicated once on each vegetation type. A total of twelve 5-acre pastures was grazed. Individual pastures were grazed at the same time each year. The nearest bunchgrass pastures were located approximately 2 miles from the corrals and scales, while the cheatgrass pastures were less than one-half mile distant.

Pastures were heavily grazed and the stocking was regulated by a putand-take system, so as to remove at least $75 \%$ of the available forage

${ }^{3}$ Proposed classification by E. W. Tisdale and M. Hironaka, College of Forestry, Wildlife and Range Sciences, University of Idaho, Moscow. 
Table 1. Precipitation (inches), temperatures $\left({ }^{\circ} \mathbf{F}\right)$, and cheatgrass yields (pounds/acre) at Saylor Creek Experimental Range during spring grazing periods, 1960-1964.

\begin{tabular}{|c|c|c|c|c|c|c|}
\hline \multirow[b]{2}{*}{ Year } & \multirow[b]{2}{*}{ Precipitation } & \multicolumn{3}{|c|}{ Temperature ${ }^{1}$} & \multirow{2}{*}{$\begin{array}{c}\text { Cheatgrass } \\
\text { yields }{ }^{2}\end{array}$} & \multirow{2}{*}{$\begin{array}{c}\text { Confidence } \\
\text { interval } \\
\left(t_{.05} \times S_{\overline{\mathbf{x}}}\right)\end{array}$} \\
\hline & & Maximum & Minimum & Average & & \\
\hline $1960^{3}$ & 0.38 & 73.7 & 39.6 & 56.6 & & \\
\hline 1961 & .39 & 64.6 & 38.0 & 51.3 & 240 & \pm 21 \\
\hline 1962 & .80 & 67.8 & 39.0 & 53.4 & 505 & \pm 21 \\
\hline 1963 & 2.55 & 60.5 & 38.7 & 49.6 & 654 & \pm 34 \\
\hline 1964 & 2.24 & 59.7 & 34.3 & 47.0 & 443 & \pm 45 \\
\hline
\end{tabular}

1 Average maximums and minimums for period.

2 Average ovendry $(70 \mathrm{C})$ weight in July on ungrazed areas. Data from another study.

${ }^{3}$ Glenns Ferry, Idaho, records.

by the end of the grazing period. The degree of use was determined by ocular estimate. Sheep were shrunk overnight (16 hr) and then weighed.

Records were kept on sheep weights and sheep-days of use. Animals were weighed at the beginning and end of each period from 19611964. Records of sheep-days of use included 1960 as well. Data for cach ycar wcre analyzcd by analysis of variance.

\section{Results and Discussion}

\section{Sheep Weight Gains and Losses}

Sheep gained an overall average of $0.32 \mathrm{lb}$. per head per day from early April to mid-May over the 4 years of study. This gain compares

Table 2. Estimated percent composition of cheatgrass and bunchgrass pastures based on basal area measurements in 1962.

\begin{tabular}{|c|c|c|}
\hline Species & Cheatgrass & Bunchgrass \\
\hline Chcatgrass $^{1}$ & 50.0 & 18.7 \\
\hline Sandberg bluegrass & 38.2 & 31.7 \\
\hline $\begin{array}{l}\text { Streambank } \\
\text { wheatgrass }\end{array}$ & 4.7 & 2.0 \\
\hline $\begin{array}{l}\text { Needle-and-thread } \\
\text { Thurber's }\end{array}$ & 0 & 16.4 \\
\hline needlegrass & 0 & 1.3 \\
\hline Big squirreltail & 0 & 2.7 \\
\hline Indian ricegrass & 0 & Trace \\
\hline Russian-thistle $\mathrm{e}^{1}$ & 5.6 & 26.3 \\
\hline Tansymustard ${ }^{1}$ & 1.5 & .8 \\
\hline Total & 100.00 & 100.00 \\
\hline
\end{tabular}

1 Density values converted to average basal area using 0.1-in. diameter as basis. favorably with sheep gains made on heavily grazed crested wheatgrass pastures in Utah (Bleak and Plummer, 1954). Differences between sheep gains on cheatgrass range and those on neeedle-andthread range over the 4 years were not significant. However, I found that sheep response varied with

period, year, and (in 1962) vegetation type (Table 3).

During the first period, the average daily loss for sheep on cheatgrass range was $0.05 \mathrm{lb}$. per head compared to the $0.14 \mathrm{lb}$. per head lost on bunchgrass range, but most of this loss can be attributed to the large loss in 1961 and smaller loss in 1963 (Table 3). The losses and small gains in the first period were attributed to stresses developed in the animals. Stresses could have been caused by transport, handling, adjustment to forage, lack of shelter, short grazing period, and sparse forage. Animals were delivered the day before they were weighed and distributed in the pastures. Most years, they came directly from winter lots on which they had shelter and a different diet. During subsequent periods, gains were similar on cheatgrass and bunchgrass ranges. In 1963, sheep lost weight during

Table 3. Daily sheep gains (pounds) and days' use per acre by year, period and vegetation type.

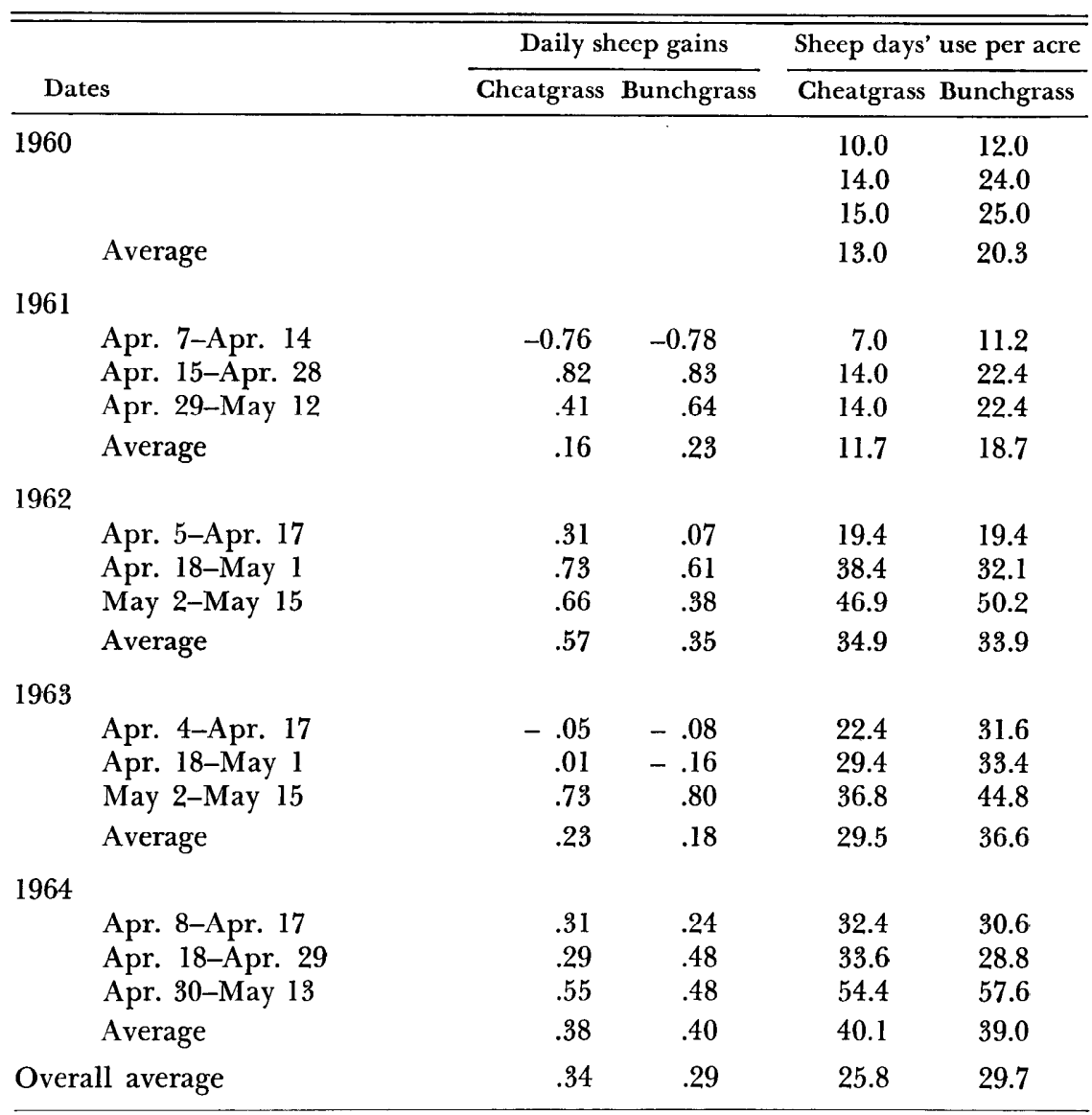


the second period in three of the four pastures. The net result was an overall loss of $0.16 \mathrm{lb}$. per head per day on bunchgrass range and a slight net gain on cheatgrass range. A heavy, wet snow, approximately 12 inches deep, covered pastures for 2 or 3 days the first week of the period; so sheep were unable to graze. Lack of forage and cold weather undoubtedly influenced animal performance.

Mean sheep gains were $0.19 \mathrm{lb}$. per head per day in 1961, 0.46 in 1962, 0.21 in 1963, and 0.39 in 1964. Differences between years are largely related to factors associated with each first period. The gains that followed each initial period reflect increased availability of cheatgrass and perennial grasses.

Sheep gains were similar on cheatgrass and bunchgrass ranges in 3 of the 4 years (Table 3). In 1962, sheep performed exceptionally well on cheatgrass range. Average gains over the three periods were $63 \%$ greater than on bunchgrass. Increased gains are attributed to the quality of forage available in the cheatgrass pastures that year. Cheatgrass growth is often slow during all of April and, sometimes, part of May. During this slow-growth period, sheep graze almost exclusively on Sandberg bluegrass. However, cheatgrass was available in April 1962 and continued to be nutritious throughout the spring. Although some green cheatgrass was available in the bunchgrass pastures, the animals were forced to ingest the dry needleand-thread from the previous year's residue; so gains were lower. As the season progressed, cheatgrass grew rapidly, particularly in the bunchgrass pastures. By the time the sheep were put into the pastures for the third period, cheatgrass was tall, rank, and dry, Sandberg bluegrass was dry, and needle-and-thread provided the only source of green feed. On cheatgrass range, vegetation was shorter and less rank. The difference betwcen growth of cheatgrass in the two types may be attributed to differences in competition for moisture.

\section{Grazing Capacity of Cheatgrass and Bunchgrass Range}

Table 3 gives the grazing capacity by year, period, and range type. Bunchgrass range, generally more productive for sheep than cheatgrass range, allowed $15 \%$ more use.

Grazing capacity increased as the season advanced on both range types. Sheep-days of use averaged 19.5 per acre the first period, 27.0 the second, and 36.7 the third. However, the bunchgrass range had a greater grazing capacity in every period than the cheatgrass range. Data collected at Saylor Creek Experimental Range when yearling cattle grazed on similar pastures over the same periods and years also indicate that bunchgrass ranges have greater grazing capacity.

The grazing capacity of 2.7 sheep approximates that of one yearling cow on either cheatgrass or bunchgrass range. The average weight of cattle during the time of the study was approximately $375 \mathrm{lb}$., while that of sheep was about $100 \mathrm{lb}$. Further consideration of cattle will not be given here.

Sheep-days of use in 1960 and 1961 were much lower than in subsequent years due to reduced forage production. However, bunchgrass range provided $56 \%$ and $60 \%$ more grazing capacity in 1960 and 1961, respectively, than cheatgrass range during these 2 dry years.

\section{Sheep Gains per Acre on Cheatgrass and Bunchgrass Range}

On the average, sheep gains per acre were similar on the two range types (Table 4) and resulted from greater capacity and lower daily gains on bunchgrass range and lowcr capacity and greater daily gains on cheatgrass range.

The seasonal effect on gains per acre follows that of daily gains and carrying capacity. Gains were lowest in the first period and highest in the last period. Over the 4 study years, total weight gain averaged $0.9 \mathrm{lb}$. per acre during the first period, $12.1 \mathrm{lb}$. per acre during the second period, and $24.0 \mathrm{lb}$. per acre during the third.
Table 4. Sheep gains per acre (pounds) on cheatgrass and bunchgrass range by year and period.

\begin{tabular}{lrr}
\hline \hline $\begin{array}{l}\text { Year and } \\
\text { period }\end{array}$ & Cheatgrass & Bunchgrass \\
\hline 1961 & & \\
1 & -5.3 & -8.7 \\
2 & 11.4 & 18.7 \\
3 & 5.8 & 14.4 \\
Average & 4.0 & 8.1 \\
1962 & & \\
1 & 6.1 & 1.4 \\
2 & 29.3 & 19.9 \\
3 & 31.0 & 20.1 \\
Average & 22.1 & 13.8 \\
1963 & & \\
1 & -1.2 & -2.6 \\
2 & .4 & -5.6 \\
3 & 26.8 & 35.8 \\
Average & 8.7 & 9.2 \\
1964 & & \\
1 & 10.0 & 7.3 \\
2 & 9.6 & 13.9 \\
3 & 30.2 & 27.6 \\
Average & 16.6 & 16.3 \\
Overall average & 12.9 & 11.9 \\
\hline
\end{tabular}

\section{Summary}

Sheep were grazed at heavy rates on cheatgrass and bunchgrass ranges for three consccutive 2-wcck periods each spring (April to mid-May) from 1960-1964. Animals grazed a new pasture each period.

Daily gains averaged $0.32 \mathrm{lb}$. per head per day and are comparable to those made on crested wheatgrass elsewhere. Sheep lost weight during the earliest period at the average rate of $0.09 \mathrm{lb}$. per day, but gained $0.58 \mathrm{lb}$. per day the last period. Differences between daily gains of sheep on cheatgrass range and daily gains of sheep on bunchgrass range were detected in only 1 (1962) of the 4 years. That year, sheep gained better on cheatgrass range, apparently because the forage was available throughout the spring.

Grazing capacities were slightly greater (29.7 days per acre) on the bunchgrass type than on the chcatgrass type (25.8 days per acre). Whether on cheatgrass or bunchgrass range, the grazing capacity 
of 2.7 sheep equaled that of one yearling cow. Capacities were influenced by growth of vegetation. During the dry years, 1960 and 1961, grazing capacities were about one-half those in subsequent wet years. Bunchgrass provided almost $60 \%$ more grazing capacity than cheatgrass in the dry years.

During comparatively wet years, cheatgrass range is equally as good as native ncedlc-and-thread bunchgrass range for spring sheep gains. However, in dry years, such as 1961 , larger daily gains, greater grazing capacity, and higher gains pcr acre may be obtained from the bunchgrass range.

Over the 4 study years, total sheep gains per acre averaged 12.9 lb. on cheatgrass range and $11.9 \mathrm{lb}$. on bunchgrass range, but these figures are not significantly different.

\section{Literature Cited}

Bleak, A. T., and A. Perry Plummer. 1954. Grazing crested wheatgrass by sheep. J. Range Manage. 7:63-68.
Cook, C. W., ANd L. E. Harris. 1952. Nutritive value of cheatgrass and crested wheatgrass on spring ranges of Utah. J. Range Manage. 5:331337.

Malde, Harold E., and Howard A. Powers. 1962. Upper Cenozoic stratigraphy of western Snake River Plains, Idaho. Geol. Soc. Amer. Bull. 73:1197-1220.

MurRay, R. B., and J. O. Klemmedson. 1968. Cheatgrass range in southern Idaho: seasonal cattle gains and grazing capacities. J. Range Manage. 21:308-313. 